\section{6. 運用について}

指令員が坑内の異常事態を人の通報または監視装置で察知 した場合は，迅速・的確に対応せねばならない。対応を迅速・ 的確に行なうには, 先ず初期の事態掌握を誤らないことが大 切である。したがつで，これを補助するため保安情報処理装 置に $\mathrm{CH}_{4}, \mathrm{CO}$, 火災検知器等の変化検出およびデータの処 理, 機器設備の運転故障状態, その他保安設備の配置状況, 緊急対応マニュアル等保安情報を入力し，必要に応じ画面を 選択しCRTに表示できるようにしている (第 4 四参照)。

因みに，指令員および補佐員は緊急の場合に備え何時でも 保安情報処理装置を駆使し，情報の収集，緊急避難，連絡報 告など間断なく的確に対応できるよう，シミュレーションに より訓練を重ねておかなければならない。

\section{7. 今後の課題}

従来人が実施していた監視を機器に置き替えるには，人に よる監視の最大の長所である総合性のある対応が低下するの でこれをいかにシステムで補えるかが最も大切である。その ためには人の判断に近いソフトの開発が鍵となる。

本システムがデータ解析に比重を置き，設備類の自動制御 等を行なわないため, 機器と人間の対応技術としては，(1) 日常の監視解析方法を規準化し教育すること，(2) 緊急時を 想定した各種の訓練を実施すること。また,機器側では日常・ 緊急時の状況をできるだけ想定して, それに対応するハード・ ソフトを整備しなければならないと考えている。

$$
\text { むすび }
$$

炭鉱の保安設備は坑内保安, 防災の要となるもので最も重要, かつ信頼性のあるものが要求される。今次, 三池炭鉱が導入した 保安情報処理システムは, 広域にわたる保安情報の監視が高い信 頼性をもつて効果的にできる点で時代の要請にマッチしたもので ある。しかし，報告した通り当所の保安の情報化は，まだ緒につ いたばかりであり, 今後の課題など残している。その意味で関係 諸兄のご指導ご批判を仰ぎさらにその応用範囲の拡大，機能の拡

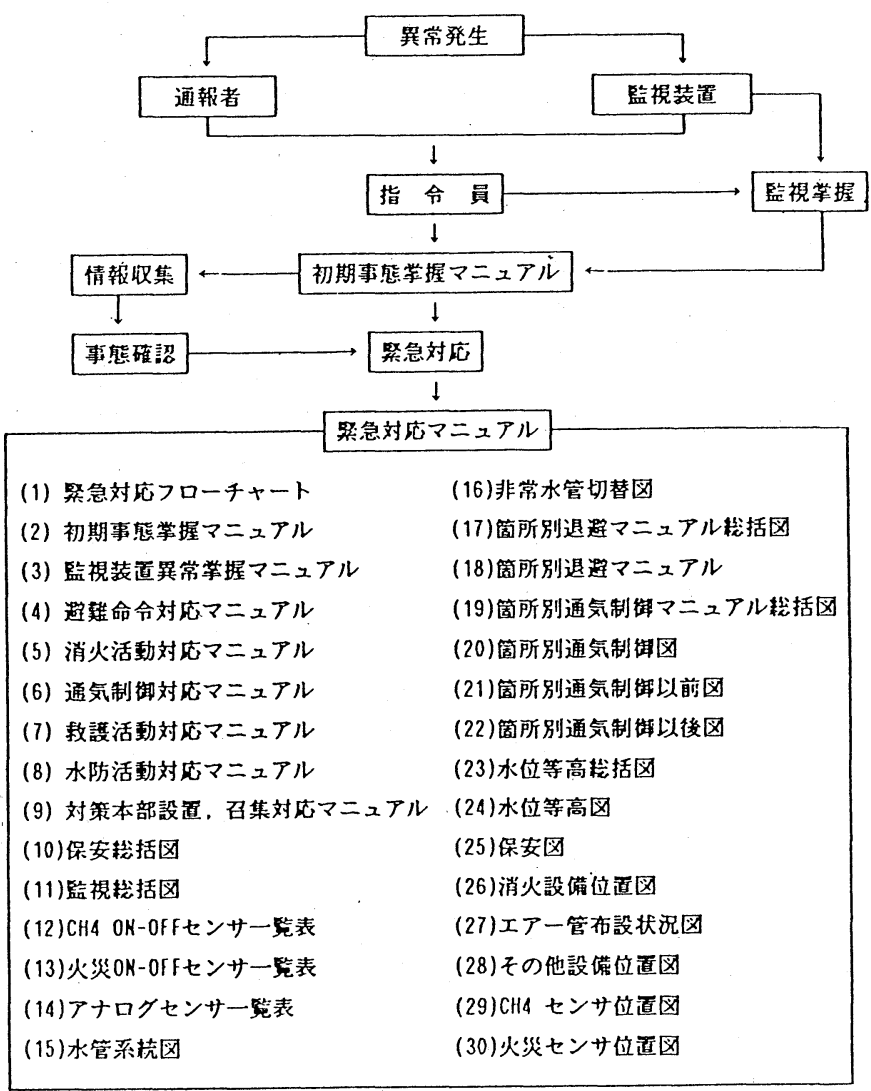

第4図緊急対応マニュアル

大と充実を図り，良いシステム作りに努め坑内保安，防災へ大い に貢献できるようにしたいと考えている。最後にこのシステムの 計画から完成にわたり，種々のご指導とご協力を賜つた三井鉱山 (株)および(株) 東芝の関係者のかたがたに対し，深く謝意を表す とともに, 本装置のソフトウェアのノウハウについては, 双方の 特許, 実用新案等に抵触するものが多々あるので念のため申し添 えるものである。

〔一般講 演〕

（20）光ファイバケーブルによる伝送回路のループ化について

松島炭鉱 (株) 池島鉱業所 小 島 博 文

\section{1. はじめに}

炭鉱における坑内集中監視装置はソフトウェア, ハードウェア 両面に亘り年々高度化してきている。当鉱の坑内集中監視装置に ついても例外でなく, 切羽関係, ポンブ座, 変電所, 主要扇風機, 運搬設備等, 監視点数の増加および監視内容が多様化してきてい る。また過去の重大災害を教訓に, $\mathrm{CH}_{4}, \mathrm{CO}$ 等の解析機能の強 化，信号伝送路の信頼性の向上，監視員の操作性，視認性の向上 が求められている。

当鉱においては, これらの問題に対応すべく昭和62年度に, 光 データリンクシステムを信号伝送路に採用した坑内集中監視装置 を設置した。本報告では，坑内集中監視装置の構成，機能，およ び特徵について述べる。

\section{2. システム構成と機能の概要}

このシステムは, $\mathrm{CH}_{4}$ 濃度, $\mathrm{CO}$ 濃度, 圧気圧力, 消火用水圧 力等のアナログ信号や, ガス自動警報器, 煙感知器, ベルトスリ ップリレー, シュートリレー, 風門開放, バック満水リレー等の 動作状態, 局部扇風機, ポンプ, ドラムカッタ, コンベヤ等の運 転状態を坑外の集中監視室の C R T にて監視を行なうとともに, ポンプ等の遠方制御を行なうよう構成されたシステムである。ま たアナログデータについては, 上限, 下限の警報設定に加え, 変 化率の解析が可能である。第 1 図にシステム構成図を示す。

機器の概要を次に示す。

(1) 中央監視制御盤 (パソコン)一式

1) 演算機能 解析機能 ( 上限下限設定, 変化率上限下限設 


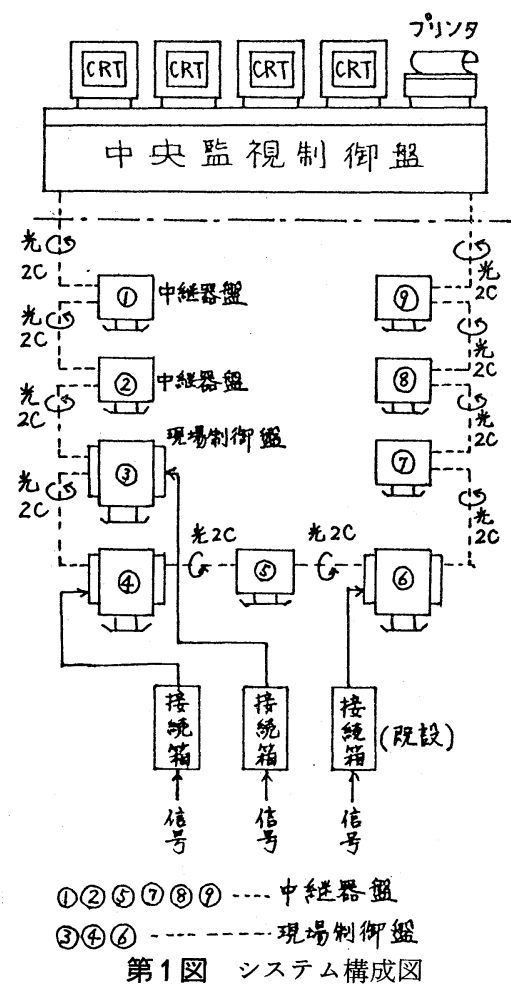

定、平均值設定 )

2）表示機能 CRTに坑内圀，各機 器のシンボル表示, アナログデータのトレ ンド表示 (グラフ)

3) CRT画面作成機能

4) データファイリング機能 記録保存

5 ) データ出力機能 プリンタ, ラン プ表示

6) 通信機能 光NET, ループバック 機能

通信方式：半二重ビットシリアル

公送速度：1.25 MBPS

公送距離：局間 $2 \mathrm{~km}$, 総延長 $30 \mathrm{~km}(1$ ル ープ)

ステーション数：親局 1 局, 子局 9 局 (中 継局舎 ) 最大 64 局可
7 ）制御機能 子局の制御
8）故障診断機能 親局異常, 子局異常, 伝送路異常
(2) 高解像度 20 インチCRT 4 台
1) 坑内図表示 各シンボル異常時赤色表示
2) トレンド表示 $\mathrm{CH}_{4}, \mathrm{CO}$
3）異常メッセージ表示 アナログデータ, 各種センサ, 機 器の運転等の状態を一覧表で表示。

4 ） システムの自己診断表示 親局, 子局, 公送路の動作状 態を表示。
（3）カラープリンタ 1 台 下記項目をプリントする。
1) 坑内図表示
2) トレンド表示
3）異常メッセージ表示
4）月報, 日報

$5 ）$ その他 CRT画面

(4) 現場制御盤 3 台

1) 現場の入出力（アナログ, ON-OFF ) の監 視制御を行なう。 $\mathrm{DI}=96$ 点, $\mathrm{DO}=32$ 点, $\mathrm{AI}=24$ 点

2) 無停電化 バッテリーにより $2 \sim 3$ 時間可能

(5) 中継器盤 6 台

1) 伝送距離の確保 局間 $2 \mathrm{~km} \quad 1$ ループ最 大 $30 \mathrm{~km}$

2）無停電化 バッテリーにより $2 \sim 3$ 時間可能

(6) 光ファイバケーブル [ G I 型ファイバラミネ

ートシースタフレックス外装PVC防食ケーブル）

\section{3. 信号伝送路の特徴}

本システムの伝送路として採用した光データリン クシステムは次のような特徵を持つている。

1）通常のデータリンク正ループと副ループ の 2 ループをリンク回線として持つているが, 通常 は正ループのみを使用する ( 第 2 図参照 )。

2) 副ループによるデータリンク＼cjkstart正ループの ケーブルが断線したり，ヶーブル接続コネクタに異 常が生じて正ループによるデータリンクが不可能と なつた場合, 自動的に副ループに切り換わり正常に データリンクを続行する(第 3 図参照)。

3) ループバックによるデータリンク正ルー ブおよび副ループのケーブルが断線したり，または 子局が電源 OFF などによりデータリンクの実行が 不可能となつた場合は, 親局からみて異常局又は異 常箇所の手前の子局でループを折り返して，データ リンク可能な局のみでリンクを続行する（第 4 図, 5 図参照)。

以上のように, 坑内に㧊いてケーブル断線, 停電 等が発生した場合, その影響を最小限にとどめ, 監 視を続行できる伀送路となつている。

\section{4. 稼 動 状}

昭和61年度より, 基本仕様の検討を行ない, 昭和 62 年 8 月までに仕様決定した。同年12月より昭和 63 年 2 月までに, ケーブルの布設, 接続, 各機器の運 搬据付けを実施した。工事期間中並行して監視員に対する教育を 実施した。CRTによる監視は視認性の向上, 容易な操作性等の面 で好評であつた。同年 3 月より本システムによる監視を開始した。 切羽の推移に合わせ, 監視内容, 名称の変更を行なつて, その機 能を十分発揮している。

\section{5. むすび}

炭鉱における坑内集中監視装置は, 保安確保にはなくてはなら ない重要な設備である。本システムの設置により, 当鉱の集中監 視装置はより一層充実したものとなつたが, 保安確保は設備だけ に頼るのではなく, 人間自身が感度の良いセンサであることが基 本だということを忘れてはならない。今後とも本システムを活用 し, 坑内保安の確保に資するよう努力していく所存である。

本システムの開発, 設置に当たりご協力いただいたメーカおよ び関係各位に深くお礼を申し上げる次第である。

\section{参 考 文 献}

「三菱FAコントローラニーザーズマニュアル」 